\title{
The Influence of Financial Flexibility on Enterprise's Profitability in the Future
}

\author{
Yunyun Cai* \\ School of Economic and Management of Jiangxi University \\ of Science and Technology \\ Ganzhou, 341000, China \\ 1066187622@qq.com
}

\author{
Yiding $\mathrm{Wu}$ \\ School of Economic and Management of Jiangxi University \\ of Science and Technology \\ Ganzhou, 341000, China \\ Wid0410@163.com
}

\begin{abstract}
With the increasing uncertainty of the contemporary economic market economy, its importance has become increasingly prominent in practice. In order to study the influence of financial flexibility on the enterprise's future profitability, this paper uses factor analysis to measure the enterprise's comprehensive profitability index, and uses two single indicators to measure the enterprise's financial flexibility. Then the effect of financial flexibility on the profitability of nonferrous metals listed companies is examined by using the bidirectional fixed effect model. The empirical results show that the influence of financial flexibility on profitability has a lag effect; Financial flexibility has a positive correlation with corporate profitability, that is, companies with relatively large financial flexibility have relatively greater profitability, and companies with relatively small financial flexibility have relatively small profitability.
\end{abstract}

Keywords-Financial flexibility; Future profitability; Factor Analysis; Bidirectional fixed effect model

\section{INTRODUCTION}

In today's unpredictable market economy environment, the increase of various kinds of risks makes the enterprises face increasing uncertainty in the course of business operations. How to achieve higher profit level in the environment of great uncertainty has become a growing concern for enterprise managers. In order to better cope with economic uncertainty, scholars introduced financial flexibility as a financial indicator. Financial flexibility is a measure of the ability of enterprises to use idle funds and residual liabilities. A large number of research results show that companies maintain a certain degree of financial flexibility and can effectively cope with economic uncertainty by adjusting idle capital reserves or using external financing opportunities. Make enterprises better in the fierce market competition has a foothold.

Future profitability, also known as profitability sustainability, refers to the ability of the company to obtain profits in the future. It reflects the operating conditions of the company from a long-term perspective and is also the most concerned issue for the owners and long-term creditors of the company. A large number of research achievements have been made by scholars at home and abroad in the field of basic profitability. These research results mainly focus on the evaluation of profitability, the design of indicators, and the influencing factors, and a relatively complete system has been formed. However, it can be found from the previous literature that there is still a lack of research on the prediction, evaluation and influencing factors of future profitability. Future profitability, as a predictive index of basic profitability, plays an increasingly important role in financial analysis with increasing market uncertainty, so it is necessary to carry out research from this aspect.

In determining the degree of financial flexibility, a series of factors such as cash holdings, dividend payments, and financial leverage policies need to be fully considered. It is a very comprehensive indicator in financial analysis. Scholars have found that it has a close relationship with the enterprise's capital structure, financial policies and corporate value. Is there a close relationship between financial flexibility and corporate profitability in the future? If so, how does financial flexibility affect future profitability? In order to achieve certain future profits, what measures can enterprises take in terms of financial flexibility? The solutions to these problems are meaningful, both in theory and in reality.

Compared with the previous related studies, the significance of this article are:

1.From the perspective of financial flexibility, to open up a new way for the study of corporate profitability.

2.Taking the non-ferrous metals industry as a sample object for research, it will broaden a feasible new way for the nonferrous metals industry to increase its profit.

\section{LITERATURE REVIEW}

The research topic of this paper is the impact of financial flexibility on the future profitability of enterprises, but considering that financial flexibility is a relatively new research area relative to profitability, this paper mainly summarizes the research results in the field of financial flexibility in the literature review, The paper also reviews the definition, source, measure method and influence on financial decision.

\section{A. The Definition, Source, Measure Method}

FASB(1984) defines financial flexibility as "the ability of a company to take effective measures to change the amount and time of cash flow based on unexpected needs and opportunities"[1]. DeAngelo believes that financial flexibility is "the ability of the company's net cash flow(NPV) to finance 
positive projects and avoid financial difficulties" [2]. Scholars such as Gamba and Triantis define financial flexibility as "the ability of the company to respond promptly to changes in cash flow and future investment opportunities"[3], similar to the definition given by FASB. Different countries, institutions and scholars have given different definitions of financial flexibility, but they generally believe that financial flexibility is a kind of capital dispatching ability for enterprises to cope with future market opportunities and possible market risks.

According to different definitions of financial flexibility, scholars believe that there are two main sources of financial flexibility, namely cash holding flexibility and debt flexibility. Through research by scholars such as Opler, it was found that due to the impact of information asymmetry on financing capacity, companies may hold more cash when the price of securities is underestimated to reduce the cost of financing[4]. Therefore, cash holding has a preventive effect. Scholar Chunai Ma found that the flexibility of asset allocation in the financial flexibility of Chinese listed companies is relatively stable, but the ability to meet cash demand is low; The structural flexibility of the capital structure can be the main source of future cash inflows, as it is possible to generate large amounts of cash inflows to enterprises[5].

For the measurement of financial flexibility, there are three main methods in the existing literature. One is the single indicator method. Scholars such as Mura and Marchica and Arslan all support the use of a single indicator to measure corporate financial flexibility. Financial leverage and cash holdings are generally used as a single indicator[6] [7]. The second is the multi-indicator combination method, which is to judge the financial flexibility of the company in combination with financial leverage and cash holdings. For example, Arslan's comprehensively reflects the financial flexibility of the company by combining financial leverage indicators and cash holdings. degree. The third is the multi-index synthesis method, which also considers multiple financial indicators that affect the financial flexibility of enterprises. For example, Machunai, a scholar in our country, draws on the existing research results. In order to build a comprehensive index of financial flexibility, he comprehensively considers three aspects: the enterprise's cash index, leverage index, and external financing cost index[8].

\section{B. Financial Implications of Financial Flexibility}

The impact of financial flexibility on corporate finance is also a focus of scholars. For example, Marchica and Mura studied the impact of financial flexibility on corporate business performance; Xinchun Zhou's research results show that the financial flexibility level is positively related to the financial flexibility level, and that properly improving the financial flexibility level of enterprises can effectively prevent risks and improve corporate performance[9]. The results of Liping Xiao found that companies have significantly increased their investment in 2-3 years after maintaining a low bar rate and a high cash holding rate[10]. Chunai Ma and Peng Jia examined the relationship between financial flexibility and corporate investment behavior and found that: Financial flexibility has a positive correlation with investment scale[11]. Jing $\mathrm{Du}$ and Chunkun Liu tested the relationship between the financial flexibility and the inefficient investment behavior of the company[12]. To sum up, the current research results on the financial impact of financial flexibility mainly focus on the impact of financial flexibility on corporate performance, investment behavior and risk prevention.

\section{Summary of Literature Review}

According to the previous literature, it can be seen that for a long time, domestic and foreign industry scholars have been very enthusiastic about the study of financial flexibility and corporate profitability. Now they have published a large number of papers and published a large number of monographs. In the existing relevant financial flexibility literature, many scholars have studied the definition of financial flexibility in the market economy environment at that time, the source of flexibility, the measurement method of flexibility, and the influencing factors, among which the definition of financial flexibility has been continuously updated. But in general, scholars believe that financial flexibility is a kind of capital dispatching ability for enterprises to cope with future market opportunities and possible market risks. For the source of financial flexibility, most scholars tend to think that corporate financial flexibility mainly comes from the view of cash holding and debt behavior. With the deepening of research, more and more scholars try to construct comprehensive measures to measure the size of financial flexibility more accurately. The influence factors of financial flexibility are gradually extending from the micro level to the macro level, gradually jumping out of the financial field of the company and looking for new perspectives that affect financial flexibility, such as the individual level of managers, market policies, and the external competition environment of the company.

Profitability refers to the ability of enterprises to use their existing funds and assets to create cash flow to obtain profits. It is an important indicator of corporate performance evaluation and has always been one of the most important financial indicators for stakeholders. Therefore, scholars at home and abroad have done more research on profitability. The relevant research results mainly focus on the relationship between profitability and corporate performance evaluation, the relationship between profitability and corporate value, the design of profitability indicators, and the factors affecting profitability, and have formed a relatively complete system. But in general, there is a lack of empirical research on the specific factors that affect the profitability of enterprises in the future. Although there are many separate studies on financial flexibility and profitability, there is very little literature that links them to analyze their relevance. According to the previous literature on financial elasticity and profitability, only the relationship between financial elasticity and corporate performance is studied. With the enhancement of the financial flexibility space consciousness of modern enterprise managers, it is necessary to study the relationship between financial flexibility and enterprise's core index, profitability, on the basis of relevant theories, so that enterprises can better obtain more profits in fierce competition, enhance the value of the enterprise. 


\section{HYPOTHESIS}

According to the theory of bankruptcy costs, as the proportion of corporate liabilities increases, fixed interest expenditure increases, profitability decreases, performance declines, and the likelihood of corporate compensation increases. This possibility of bankruptcy leads to a series of negative effects that affect the profitability of the enterprise. Eventually led to a decline in market value. Financial flexibility affects the proportion of short-term debt and the proportion of highly binding debt. Therefore, the following assumptions are put forward in this paper:

H1: There is a positive correlation between financial flexibility and corporate profitability.

According to the theory of financial flexibility, financial flexibility refers to the ability of an enterprise to allocate capital to meet future risks and challenges, that is, financial flexibility benefits may be more reflected in a certain period of time in the future. Therefore, the study of the impact of financial flexibility on future profitability cannot be limited to annual analysis. It should require a financial flexibility buffer period. Therefore, we assume that the impact of financial flexibility companies on corporate profitability has a lag period.

$\mathrm{H} 2$ : There is a lag effect on the impact of financial flexibility on profitability.

\section{DATA AND METHODS}

\section{A. Sample Selection}

The non-ferrous metals listed companies in Shanghai and Shenzhen from 2013 to 2017 were selected as research samples. Although the sample range of this paper is 20132017, the actual data source is from 2011 due to the delayed processing of financial flexibility. The data are screened and collated according to the following principles: (1) Remove companies that were newly listed and delisted during the research period; (2)Remove ST and *ST company; (3)Eliminate companies that have missing key variables. 62 sample company data were finally obtained. In order to reduce the effect of outliers, Winsorize is applied to the data of all continuous variables between $0 \% \sim 1 \%$ and $99 \% \sim 100 \%$. The data are taken from the Choice financial database. The data processing and statistical analysis software is Excel2016, SPSS21.0 and STATA 11.0.

\section{B. Measuring Comprehensive Profitability Index}

\section{1) Selection of measurement indicators}

12 indicators were taken for the construction of a profit index measurement system. These indicators reflect the profitability of non-ferrous metals listed companies in terms of asset use efficiency, capital use efficiency, shareholder equity, return on stock investment, profitability of the main business, and sales revenue. The method of factor analysis in principal component analysis is used in the construction of comprehensive index. The indicators are shown in table 1:
TABLE I. PROFITABILITY INDICATORS

\begin{tabular}{|l|l|l|c|}
\hline Code & Indicator & Form ula & Nature \\
\hline X1 & Return on assets & Net profit/average total assets $* 100 \%$ & + \\
\hline X2 & Inventory turnover & Operating cost/average inventory & + \\
\hline X3 & Working capital turnover & $\begin{array}{l}\text { Net sales/(average current assets }- \\
\text { average current liabilities } * 100 \%\end{array}$ & + \\
\hline X4 & Return on capital & $\begin{array}{l}\text { Average net profit/owner's equity } \\
\text { balance } * 100 \%\end{array}$ & + \\
\hline X5 & Return on equity & $\begin{array}{l}\text { Net profit/year-end shareholders' } \\
\text { equity } * 100 \%\end{array}$ & + \\
\hline X6 & Earnings per share & Net profit/total equity & + \\
\hline X7 & Earnings per share before tax & Ebit/equity & + \\
\hline X8 & Profit margin of main business & $\begin{array}{l}\text { Profit of main business/net income of } \\
\text { main business } * 100 \%\end{array}$ & + \\
\hline X9 & Gross margin on sales & $\begin{array}{l}\text { (net sales income }- \text { product cost) } / \text { net } \\
\text { sales income } * 100 \%\end{array}$ & + \\
\hline X10 & Net sales profit & Net profit/sales income $* 100 \%$ & + \\
\hline X11 & Net interest rate on total asset & $\begin{array}{l}\text { Net interest rate/average total } \\
\text { assets } * 100 \%\end{array}$ & + \\
\hline X12 & Cost margin & Total profit/total cost $* 100 \%$ & + \\
\hline & & & + \\
\hline
\end{tabular}

2) Calculation procedure of the comprehensive index of profitability

TABLE II. KMO AND BARTLETT TEST

\begin{tabular}{|c|c|r|}
\hline \multicolumn{3}{|c|}{ KM0 and Bartlett test } \\
\hline The Kaiser- Meyer-Olkin measure of sampling adequacy. & 0.886 \\
\hline \multirow{4}{*}{ Bartlett's sphericity test } & The approximate chi-square & 6113.771 \\
\cline { 2 - 3 } & $\mathrm{df}$ & 66 \\
\cline { 2 - 3 } & Sig. & 0.000 \\
\hline
\end{tabular}

In order to make the data more comparable, in the process of factor analysis, this paper summarized the data of the five years from 2013 to 2017 , conducted a factor analysis in the SPSS software, and then constructed the comprehensive index model of profitability based on the component score coefficient matrix and variance contribution rate.

In this paper, KMO and Bartlett were used to test the correlation between variables, and the data were shown in table 2 . The KMO test value was 0.886 , significantly greater than 0.5 and close to 0.9 , indicating that it was suitable for principal component analysis, while the SIG value of Bartlett's sphericity test was $0.00<0.05$, rejecting the null hypothesis, and the correlation of variables was significant.

According to the standard that the eigenvalue is greater than 1, 3 factors are extracted from 12 variables, as shown in table 3. Denoted as F1, F2 and F3, F1's variance contribution rate is $60.204 \%, \mathrm{~F} 2$ 's variance contribution rate is $11.929 \%$, F3's variance contribution rate is $8.34 \%$, and the cumulative variance rate of the first three common factors reaches $80.47 \%$, indicating that these three factors can explain the information of the original indicator of $80.473 \%$. 
TABLE III. TOTAL VARIANCE OF INTERPRETATION

\begin{tabular}{|c|r|r|r|r|r|r|r|r|r|}
\hline \multirow{2}{*}{$\begin{array}{c}\text { Ingre- } \\
\text { dients }\end{array}$} & \multicolumn{3}{|c|}{ Initial eigenvalue } & \multicolumn{3}{c|}{$\begin{array}{c}\text { Extract the sum of } \\
\text { squares and load }\end{array}$} & \multicolumn{3}{c|}{$\begin{array}{c}\text { Rotate the sum of } \\
\text { squares to Load }\end{array}$} \\
\cline { 2 - 11 } & \multicolumn{1}{c|}{ tot } & var\% & cus \% & tot & var \% & cus \% & tot & var \% & cum\% \\
\hline 1 & 7.378 & 61.481 & 61.481 & 7.378 & 61.481 & 61.481 & 7.225 & 60.204 & 60.204 \\
\hline 2 & 1.278 & 10.653 & 72.134 & 1.278 & 10.653 & 72.134 & 1.431 & 11.929 & 72.133 \\
\hline 3 & 1.001 & 8.34 & 80.473 & 1.001 & 8.34 & 80.473 & 1.001 & 8.34 & 80.473 \\
\hline 4 & 0.95 & 7.919 & 88.392 & & & & & & \\
\hline 5 & 0.604 & 5.03 & 93.422 & & & & & & \\
\hline 6 & 0.351 & 2.928 & 96.35 & & & & & & \\
\hline 7 & 0.168 & 1.398 & 97.747 & & & & & & \\
\hline 8 & 0.095 & 0.788 & 98.535 & & & & & & \\
\hline 9 & 0.079 & 0.656 & 99.192 & & & & & & \\
\hline 10 & 0.055 & 0.458 & 99.649 & & & & & & \\
\hline 11 & 0.025 & 0.205 & 99.854 & & & & & & \\
\hline 12 & 0.017 & 0.146 & 100 & & & & & & \\
\hline
\end{tabular}

TABLE IV. ROTATION COMPONENT MATRIX

\begin{tabular}{|c|c|c|c|}
\hline \multirow{2}{*}{} & \multicolumn{3}{|c|}{ Ingredients } \\
\cline { 2 - 4 } & 1 & 2 & 3 \\
\hline X11 & 0.949 & 0.011 & -0.014 \\
\hline X4 & 0.916 & -0.006 & 0.02 \\
\hline X6 & 0.91 & -0.034 & 0.023 \\
\hline X10 & 0.881 & -0.01 & -0.023 \\
\hline X8 & 0.861 & 0.286 & -0.007 \\
\hline X7 & 0.853 & 0.271 & -0.005 \\
\hline X12 & 0.841 & 0.031 & 0.019 \\
\hline X5 & 0.833 & 0.342 & -0.001 \\
\hline X2 & 0.136 & -0.062 & -0.015 \\
\hline X9 & 0.561 & -0.851 & 0.009 \\
\hline X3 & -0.002 & 0.654 & 0.014 \\
\hline
\end{tabular}

TABLE V.

COMPONENT SCORE COEFFICIENT MATRIX

\begin{tabular}{|c|c|c|c|}
\hline \multirow{2}{*}{} & \multicolumn{3}{|c|}{ Ingredients } \\
\cline { 2 - 4 } X1 & 1 & 2 & 3 \\
\hline X2 & 0.135 & -0.097 & -0.024 \\
\hline X3 & 0.107 & -0.666 & 0.006 \\
\hline X4 & 0.001 & 0.002 & 0.998 \\
\hline X5 & 0.131 & -0.097 & 0.019 \\
\hline X6 & 0.142 & -0.131 & -0.017 \\
\hline X7 & 0.124 & -0.118 & 0.022 \\
\hline X8 & 0.102 & -0.061 & 0.018 \\
\hline X9 & 0.019 & 0.122 & -0.006 \\
\hline X10 & 0.102 & 0.444 & 0.016 \\
\hline X11 & 0.143 & -0.088 & -0.007 \\
\hline X12 & 0.092 & 0.178 & -0.015 \\
\hline
\end{tabular}

Extraction method: Principal component.

Rotation method: Orthogonal rotation method with Kaiser standardization. ${ }^{\text {a }}$ The rotation converges after 3 iterations.

As can be seen from table 4, there are three constituent factors. The inverse calculation of the factor load matrix after orthogonal transformation is obtained to obtain the component score coefficient Matrix, as shown in Table 5. According to the degree of influence of the original variable on the main factor, three linear equations of the main factor can be obtained, as follows:
$\mathrm{F} 1=0.135 \mathrm{X} 1+0.107 \mathrm{X} 2$

$0.001 \mathrm{X} 3+0.140 \mathrm{X} 4+0.131 \mathrm{X} 5+0.142 \mathrm{X} 6+0.124 \mathrm{X} 7+0.102 \mathrm{X} 8+0$. $019 \times 9+0.102 \times 10+0.143 \times 11+0.092 \times 12$

$\mathrm{F} 2=-0.097 \times 1-0.666 \times 2+0.002 \times 3-0.097 \times 4-0.131 \times 5-$ $0.118 \times 6-0.061 \times 7+0.122 \times 8+0.444 \times 9+0.132 \times 10-$ $0.088 \mathrm{X} 11+0.178 \mathrm{X} 12$

$\mathrm{F} 3=-0.024 \mathrm{X} 1+0.006 \times 2+0.998 \times 3+0.019 \times 4-$ $0.017 \times 5+0.022 \times 6+0.018 \times 7-0.006 \times 8+0.016 \times 9-0.007 \times 10-$ $0.015 \times 11-0.001 \times 12$

Among them, $\mathrm{X}$ represents the standardized single indicator data.

Combining the variance contribution rate of table 3 , the model of the comprehensive indicator $\mathrm{P}$ of profitability is:

\section{$\mathrm{P}=0.602 \mathrm{~F} 1+0.119 \mathrm{~F} 2+0.083 \mathrm{~F} 3$}

\section{Model Construction}

In this paper, we take the enterprise's future profitability as the dependent variable, reduce the number of variables by Factor Analysis, and establish a comprehensive index model of profitability. The independent variable is financial flexibility, the measure of financial flexibility is obtained by calculating the cash elasticity and the debt financing elasticity. According to existing theories and empirical studies, corporate profitability is also affected by enterprise scale, asset turnover rate, ownership concentration, operating income growth rate and other factors ,So this paper add total assets(SIZE), turnover of total capital(TAT), ownership concentration(TOPL), increase rate of business revenue (OIGR) as controlled variables. And then the influence of financial flexibility on the enterprise's future profitability is verified by multivariate linear regression method.

In order to investigate the impact of financial flexibility on the future profitability of the enterprise, and considering the nature of panel data, this paper considers the individual effect and time effect, and adopts the two-way fixed effect model to analyze. In order to test the hypothesis and learn from the previous scholars 'relevant research ideas, this paper establishes the panel data model as follows:

\section{$P_{i, t}=\boldsymbol{\alpha}_{0}+\boldsymbol{\alpha}_{1} S D C_{i, t-2}+\boldsymbol{\alpha}_{2} S_{I Z E_{i, t}}+\boldsymbol{\alpha}_{3} T_{A T_{i, t}}+\boldsymbol{\alpha}_{4}$ TOPL $_{i, t}+\boldsymbol{\alpha}_{5} \mathrm{OIGR}_{i, t}+\boldsymbol{\mu}_{i}+\lambda_{t}+\boldsymbol{e}$ $i, t$ \\ $\boldsymbol{\mu}_{i}$ is individual effects, $\boldsymbol{\lambda}_{\boldsymbol{t}}$ is time effect, $\boldsymbol{e}_{i, t}$ is random perturbation term}

Considering that the impact of financial flexibility on profitability may take a period of time to be reflected, this study designed the interpretation variable and the interpreted variable to be delayed by two periods. In order to verify hypothesis 1 and 2, this paper first uses the balance panel data of non-ferrous metals listed companies from 2013 to 2017 as the research sample, and uses the above model for regression analysis. If the two assumptions are established, it is expected that the regression coefficient $\alpha 1$ of the SDC is positive, which indicates that the financial elasticity has a significant positive effect on profitability, and this effect has a lag effect. 


\section{EMPIRICAL RESEARCH PROCESS}

\section{A. Descriptive statistics of the Main Variables}

TABLE VI. DESCRIPTIVE STATISTICS

\begin{tabular}{|c|c|c|c|c|c|}
\hline & Min & Max & Mean & p50 & Sd \\
\hline P & -2.250 & 2.794 & -0.019 & -0.392 & 0.714 \\
\hline SDC & -1.019 & 1.251 & 0.560 & 0.777 & 0.340 \\
\hline SIZE & 20.019 & 25.971 & 22.251 & 22.251 & 1.293 \\
\hline TAT & 0.189 & 7.305 & 1.066 & 0.803 & 1.027 \\
\hline TOPL & 0.000 & 0.705 & 0.338 & 0.348 & 0.145 \\
\hline OIGR & -0.361 & 1.101 & 0.11 & 0.074 & 0.264 \\
\hline
\end{tabular}

The table 6 shows that the combined earnings index for 2013-2017 has a minimum of -2.25 and a maximum of 2.79 , indicating that the profitability levels of different companies in the non-ferrous metals industry vary greatly, with an average index of -0.019 . This shows that the overall profit level of the non-ferrous metals industry is low. The minimum financial flexibility is -1.019 and the maximum value is 1.251 , indicating that the financial flexibility of different companies in the nonferrous metals industry differs greatly. OIGR is the growth rate of operating income, with a minimum value of -0.361 , a maximum value of 1.101 , and an average of 0.11 . In general, the level of operating income growth among different companies in the non-ferrous metals industry differs greatly, but the average operating income growth of the industry is better. Above $10 \%$, This shows that the non-ferrous metals industry has a higher profitability of products in the past five years

\section{B. Multicollinearity Test}

TABLE VII. CORRELATION TEST

\begin{tabular}{|c|l|l|l|l|l|l|}
\hline 变量 & $\mathrm{P}$ & SDC & SIZE & TAT & TOPL & OIGR \\
\hline P & 1.000 & & & & & \\
\hline SDC & 0.008 & 1.000 & & & & \\
\hline SIZE & $-0.156^{* * *}$ & $0.131^{* *}$ & 1.000 & & & \\
\hline TAT & -0.010 & 0.0490 & -0.064 & 1.000 & & \\
\hline TOPL & $-0.147^{* * *}$ & -0.089 & $0.162^{* * * *}$ & -0.028 & 1.000 & \\
\hline 0IGR & $0.419^{* * * *}$ & -0.002 & 0.001 & 0.0910 & $-0.124^{* * * *}$ & 1.000 \\
\hline \multicolumn{7}{|c|}{ Note: ***,***, are significant at $1 \%, 5 \%$, and $10 \%$ confidence levels, }
\end{tabular}
respectively; Same below.

The so-called correlation test is to test whether there is a correlation between numerous independent variables and dependent variables, and at the same time, to see the degree of collinearity between independent variables. If the correlation between independent variables is very large, it means that collinearity may exist.

As can be seen from table 7 , although there is a certain correlation between the various variables, the correlation coefficient is not higher than 0.5. It is generally believed that when the Pearson correlation coefficient of all variables is lower than the colinear threshold of 0.7 , there will be no serious multiple colinear problems in the empirical analysis, so the research conclusions of this paper will not be affected by multiple colinear problems. In addition, from the point of view of Pearson between variables, the size of the company, the total asset turnover rate, and the equity centralism are negatively correlated, and the financial elasticity, the growth rate of operating income, and profitability are positively correlated, but this correlation only considers the correlation between the two variables. The impact of other factors was ignored and further regression tests were needed.

\section{Empirical Results and Analysis}

TABLE VIII. MULTIPLE REGRESSION RESULT

\begin{tabular}{|c|c|c|c|c|c|c|}
\hline & \multicolumn{2}{|c|}{ Lag phase 0 } & \multicolumn{2}{c|}{ Lag phase 1 } & \multicolumn{2}{c|}{ Lag phase 2 } \\
\hline & coef & $\mathrm{t}$ & coef & $\mathrm{t}$ & coef & $\mathrm{t}$ \\
\hline SDC & 0.016 & 0.08 & 0.148 & 1.13 & $0.332^{* * *}$ & 2.67 \\
\hline SIZE & $0.481^{*}$ & 1.84 & $0.473^{*}$ & 1.82 & $0.498^{*}$ & 1.92 \\
\hline TAT & 0.229 & 1.63 & 0.219 & 1.58 & $0.288^{* *}$ & 2.01 \\
\hline TOPL & -0.123 & -0.16 & -0.127 & -0.17 & -0.211 & -0.27 \\
\hline OIGR & $0.457^{* *}$ & 2.61 & $0.454^{* *}$ & 2.58 & $0.398^{* *}$ & 2.11 \\
\hline Time & contro1 & contro1 & control & control & control & contro1 \\
\hline con & $-10.98^{*}$ & -1.9 & $-10.79^{*}$ & -1.88 & $-11.410^{*}$ & -1.99 \\
\hline Adj. $R^{2}$ & \multicolumn{2}{|c|}{0.198} & \multicolumn{2}{c|}{0.203} & \multicolumn{2}{c|}{0.227} \\
\hline N & \multicolumn{2}{|c|}{310} & \multicolumn{2}{c|}{310} & \multicolumn{2}{c|}{310} \\
\hline
\end{tabular}

Table 8 is the regression results of the independent variables of financial flexibility lagging behind 0 , lagging behind 1 and lagging behind 2 respectively. From the regression results, it can be seen that the coefficient of financial flexibility is 0.016 in the 0 period, but there is no correlation between financial flexibility and corporate profitability, and there is no significant effect on financial elasticity and profitability in the 1 period, but the coefficient of financial elasticity in the 2 periods of lag is 0.332 ., It is significant at 1 $\%$ level, which shows that financial flexibility has a significant impact on profitability and is a positive correlation. The three regression results test the previous two assumptions: that financial flexibility has a positive effect on profitability and that there is a lag period.

It should be noted that in addition to the significant impact of financial flexibility on corporate profitability, the scale factors and operating income growth rates in the selected control variables also have a significant impact on the profitability of the company, with significant levels of $10 \%$ and $5 \%$ respectively.

\section{RESEARCH CONCLUSIONS AND DISCUSSION}

(1) There is a positive correlation between financial flexibility and corporate profitability, that is, enterprises with relatively high financial flexibility have relatively greater profitability; Companies with lower financial flexibility are also relatively less profitable. By enhancing the ability of enterprises to cope with future risks and opportunities and promoting the efficient and reasonable use of resources in the course of future operations, enterprises can maintain good 
financial flexibility and provide good financial support for the growth of corporate profitability.

(2) The impact of financial flexibility on profitability has a lag effect. That is to say, the impact of financial flexibility on the profitability of companies has a lag period of several years. In the non-ferrous metals industry in this article, financial flexibility companies are implementing financial flexibility policies in the current period because companies need to adopt conservative financial policies (or hold a certain amount of cash, or reduce external borrowing. According to the theory of capital cost, more scholars now tend to maintain the financial flexibility of companies by reducing external borrowing.) This has somewhat affected the profitability of companies in the current period. Therefore, the correlation between financial flexibility and profitability is not significant. There was also no significant impact on profitability in the first year after maintaining financial flexibility, but in the second year, the impact of financial flexibility on profitability was significantly positive, indicating that there was a lag in the impact of financial flexibility on future profitability.

\section{REFERENCES}

[1] FASB.SFAC No.5 : Recognition and Measurement in the Financia Statements of Business Enterprises. New York: Financial Accounting Standard Board, 1984: CON5-11.
[2] Deangelo H, Deangelo L. Capital Structure, Payout Policy, and Financial Flexibility. Social Science Electronic Publishing.2007

[3] Gamba A, Triantis A. The Value of Financial Flexibility. Journal of Finance, 2008, 63(5):2263-2296.

[4] Opler T, Pinkowitz L, René Stulz, et al. The determinants and implications of corporate cash holdings. 1999, 52(1):3-46.

[5] Chunai Ma. Research on Financial Elastic Sources of Listed Companies. Financial Communications, 2017(17):68-70.

[6] Mura R, Marchica M T. Financial Flexibility, Investment Ability and Firm Value: Evidence from Firms with Spare Debt Capacity. Financial Management, 2010, 39(4):1339-1365.

[7] Arslan-Ayaydin, Florackis C, Ozkan A. Financial flexibility, corporate investment and performance: evidence from financial crises. Review of Quantitative Finance and Accounting, 2014, 42(2):211-250.

[8] Chunai Ma. Construction and Empirical Analysis of Enterprise Financial Elastic Index. System Engineering, 2010, 28(10):61-66.

[9] Xinchun Zhou. Financial flexibility, risk prevention and performance. Financial Communications,2012(23):28-29.

[10] Liping Xiao, Zhe Li. Impact of Financial Flexibility on Corporate Investment and Performance. Friends of Accounting, 2015(7):37-40.

[11] Chunai Ma, Peng Jia. Relationship between Enterprise Financial Flexibility and Investment Behavior: A Data Test in a Financial Crisis Environment . Financial Theory and Practice, 2015(3):46-49.

[12] Jing Du and Chunkun Liu. Empirical test on the influence of financial flexibility on inefficient investment of enterprises . Accounting Monthly, 2016(2):60-65. 